\title{
Indian Society of Critical Care Medicine Experts Committee Consensus Statement on ICU Planning and Designing, 2020
}

Narendra Rungta ${ }^{1}$, Kapil Gangadhar Zirpe ${ }^{2}$, Subhal B Dixit ${ }^{3}$, Yatin Mehta ${ }^{4}$, Dhruva Chaudhry ${ }^{5}$, Deepak Govil ${ }^{6}$, Rajesh C Mishra ${ }^{7}$, Jeetendra Sharma ${ }^{8}$, Pravin Amin ${ }^{9}$, BK Rao ${ }^{10}$, GC Khilnani ${ }^{11}$, Kundan Mittal ${ }^{12}$, Pradip Kumar Bhattacharya ${ }^{13}$, AK Baronia ${ }^{14}$, Yash Javeri ${ }^{15}$, Sheila Nainan Myatra ${ }^{16}$, Neena Rungta ${ }^{17}$, Ranvir Tyagi ${ }^{18}$, Sanjay Dhanuka ${ }^{19}$, Mahesh Mishra ${ }^{20}$, Srinivas Samavedam ${ }^{21}$

\begin{abstract}
Background: Indian Society of Critical Care Medicine (ISCCM) guidelines on Planning and Designing Intensive care (ICU) were first developed in 2001 and later updated in 2007. These guidelines were adopted in India, many developing Nations and major Institutions including NABH. Various international professional bodies in critical care have their own position papers and guidelines on planning and designing of ICUs; being the professional body of intensivists in India ISCCM therefore addresses the subject in contemporary context relevant to our clinical practice, its variability according to specialty and subspecialty, quality, resource limitation, size and location of the institution. Aim: To have a consensus document reflecting the philosophy of ISCCM to deliver safe \& quality Critical Care in India, taking into consideration the requirement of regulatory agencies (national \& international) and need of people at large, including promotion of training, education and skill upgradation. It also aiming to promote leadership and development and managerial skill among the critical care team. Material and Methods: Extensive review of literature including search of databases in English language, resources of regulatory bodies, guidelines and recommendations of international critical care societies. National Survey of ISCCM members and experts to understand their viewpoints on respective issues. Visiting of different types and levels of ICUs by team members to understand prevailing practices, aspiration and Challenges. Several face to face meetings of the expert committee members in big and small groups with extensive discussions, presentations, brain storming and development of initial consensus draft. Discussion on draft through video conferencing, phone calls, Emails circulations, one to one discussion Result: Based upon extensive review, survey and input of experts' ICUs were categorized in to three levels suitable in Indian setting. Level III ICUs further divided into sub category A and B. Recommendations were grouped in to structure, equipment and services of ICU with consideration of variation in level of ICU of different category of hospitals. Conclusion: This paper summarizes consensus statement of various aspect of ICU planning and design. Defined mandatory and desirable standards of all level of ICUs and made recommendations regarding structure and layout of ICUs. Definition of intensive care and intensivist, planning for strength of ICU and requirement of manpower were also described.

Keywords: Critical care, Health care workers (HCW) , HDU, Healthcare, hospital, ICU (Intensive Care Unit), ICU beds, ICU doctors, India. Indian Journal of Critical Care Medicine (2020): 10.5005/jp-journals-10071-G23185
\end{abstract}

\section{Preamble}

Indian Society of Critical Care Medicine (ISCCM) guidelines on planning and designing ICU were first developed in 2001 and later updated in 2007. These guidelines were adopted in India, many developing nations and major institutions including NABH. Critical Care Medicine, now, has the status of super-specialty having DM, three-year DNB (two-year FNB earlier), PDCC training program besides certification/diploma/fellowship programs, namely IDCCM, IFCCM and CTCCM of ISCCM. Also, ISCCM has a critical care training/ diploma for nurses (IDCCN) in India. ISCCM, at present, has more than 12,000 members, 2000 quality ICUs, 65 IFCCM centers, and more than 200 ICUs running IDCCM, CTCCM and IDCCN courses. Various international professional bodies in critical care have their own position papers and guidelines on planning and designing of ICUs; being the professional body of intensivists in India, ISCCM, therefore addresses the subject in contemporary context relevant to our clinical practice, its variability according to specialty and subspecialty, quality, resource limitation, size and location of the institution.

\section{Aıms}

- To have a consensus document reflecting the philosophy of ISCCM to deliver safe and quality critical care in India, taking into
Corresponding Author: Jeetendra Sharma, Department of Critical Care, Artemis Health Institute, Gurgaon, Haryana, India, Phone: 7042118485, e-mail: drjeetendrasharma@gmail.com

How to cite this article: Rungta N, Zirpe KG, Dixit SB, Mehta Y, Chaudhry D, Govil D, et al. Indian Society of Critical Care Medicine Experts Committee Consensus Statement on ICU Planning and Designing, 2020. Indian J Crit Care Med 2020;24(Suppl 1):S43-S60.

Source of support: Nil

Conflict of interest: None

consideration the requirement of regulatory agencies (national and international) and need of people at large.

- To meet aspirations and practical needs, across spectrum of health institutions without compromising on safety and quality of care, by promoting training, education and skill upgradation. Simultaneously, to provide safe, quality, professional, ethical, flexibility, without compromising standard of care, and responsive environment to healthcare professionals, namely doctors, nurses and other paramedics along with development of leadership and managerial skill among the critical care team.

- To promote leadership development and managerial skill among the critical care team

(C) The Author(s). 2020 Open Access This article is distributed under the terms of the Creative Commons Attribution 4.0 International License (https://creativecommons. org/licenses/by-nc/4.0/), which permits unrestricted use, distribution, and non-commercial reproduction in any medium, provided you give appropriate credit to the original author(s) and the source, provide a link to the Creative Commons license, and indicate if changes were made. The Creative Commons Public Domain Dedication waiver (http://creativecommons.org/publicdomain/zero/1.0/) applies to the data made available in this article, unless otherwise stated. 


\section{Objectives}

- To define intensive/critical care, ICU and HDU

- To describe different levels of ICUs according to intensity of care provided

- To define intensivist/critical care specialist

- To describe medical professional who can practice intensive/ critical care

- Recommendations on design and requirements of ICUs

- Recommendations on human resource

- To reinforce infection control policy

- Emergency preparedness

- To promote training and research

- Meeting medical and paramedical professional expectations

- Meeting family expectations

- Leaving scope for future expansion

\section{Methodology Adopted to Write the DOCUMENT}

- Extensive review of literature including search of databases in English language, resources of regulatory bodies, guidelines and recommendations of international critical care societies

- National survey of ISCCM members and experts to understand their viewpoints on respective issues. Taking/recording individuals opinion/ experiences to understand prevailing practices, aspiration and challenges by visiting different types and levels of ICUs

- Several face-to-face meetings of the expert committee members in big and small groups with extensive discussions, presentations, brainstorming and development of initial consensus draft, further discussion on draft through video conferencing, phone calls and e-mail circulation.

\section{Consensus Statement For ICU Planning AND DESIGN \\ Levels of ICU and High Dependency Unit ${ }^{2-12}$}

Level I (Recommended for Hospitals including Nursing Homes up to 50 Beds, District Hospitals/Community Health Centers up to 100 Beds)

- Number of beds-6 to 8

- Should be able to perform cardiopulmonary resuscitation including intubation, short-term cardiorespiratory support including, non-invasive ventilation, and defibrillation

- Provision for short-term mechanical ventilation (desirable)

- Have syringe pumps/infusion pumps

- Have multipara monitors with $\mathrm{SPO}_{2}, \mathrm{HR}$ and ECG, NIBP, temperature facility

- Access to ABG facility

- Access to ultrasound, X-ray and basic clinical lab (CBC, blood sugar, electrolytes, LFT and RFT).

- Desirable to have access to CT scan and microbiology

- Access to ambulance (ACLS desirable) and trained manpower for safe transport of the patients to higher level centers

- Doctors should be encouraged to participate short-term training courses/workshops like FCCS/4C /ACLS/mechanical ventilation, etc.

- Access to $24 \times 7$ blood bank/pharmacy/nutrition (desirable)

- Provision for telemedicine consultations (desirable)
- At least one book and one journal of critical care medicine should be available as ready reckoner

- General infection control and, patients and staff safety measures should be observed

Level II (Recommended for Larger General Hospitals up to 100 to 150 Beds)

It includes all recommendations of Level I in addition to the following requirements:

- Number of beds 8 to 12

- HOD/Director/In-charge of the ICU should be an intensivist and be qualified/trained/certified in critical care

- Facility for multisystem organ support.

- Central nursing station (CNS)/central monitoring facility

- Provision of both invasive and non-invasive ventilation (preferably up to half to two-thirds of bed strength)

- Access to renal replacement therapy (RRT)

- Transcutaneous pacing facility

- Microbiology support with facility for fungal identification (desirable)

- Nurses and duty doctors are trained/certified in critical care

- Should have ABG, bedside X-ray and ultrasound $24 \times 7$

- Access to CT and MRI

- Protocols and policies for ICUs must be there and are observed

- Research should be encouraged

- Should have access to super-specialties of medicine and surgery

- High dependency unit (HDU) facility and telemedicine are desirable

- Should have access to e-journals, databases and books

Level III (For Tertiary Care Hospitals >150 Beds including

Medical Colleges and Corporate Hospitals)

It includes all recommendations of Level II; in addition, must have following facilities/provisions:

(Level III is further sub-classified into A and B on the basis of provision of extreme care services. Level IIIB provides extracorporeal therapies in addition to facilities available in Level IIIA)

Level III $A$

- Critical care unit should preferably be a closed ICU

- Protocols and policies are defined

- Must have provision of advanced cardiorespiratory monitoring - both invasive and non-invasive

- Intra- and inter-hospital transport facilities available

- Multisystem care and referral available round the clock

- Should become lead center for teaching and training in critical care

- $\quad$ Ultrasound and echocardiography in the ICU $24 \times 7$

- In-house blood bank, pharmacy and canteen services $24 \times 7$

- In-house CT scan and MRI facilities strongly recommended

- Bedside flexible bronchoscopy facility is desirable

- Bedside renal replacement therapy (RRT)

- Continuous renal replacement therapy (CRRT) and plasma exchange facility are recommended

- Optimum patient/nurse ratio (1:1 on patients on organ support e.g. mechanical ventilation, RRT, multiple inotropes; and 1:2 at least when patient is on non-invasive ventilation and/or requires less intense monitoring)

- Should follow guidelines of a professional body of critical care (ISCCM) or equivalent in terms of ICU structure 
- Should act as a center for research, training and teaching, including tele-consultations and telemedicine center

- Should be equipped for both long-term acute care and palliative care

- Team should be well versed with transplant critical care

Level IIIB

All of the above plus ECMO-, $\mathrm{ECCO}_{2} \mathrm{R}$ - and LV-assist devices

\section{High Dependency Unit (HDU) ${ }^{11}$}

- This is an area where patient care level is intermediate between ICU and other floors.

- It should be located near the ICU or within ICU complex, near emergency or in a ward.

- The nursing and supportive staff should have critical care experience/training.

- Patients after recovery from critical illness, patients of single organ failure and not requiring invasive monitoring or mechanical ventilation but need close observation due to vulnerability for deterioration preferably be admitted in HDU.

- $\quad$ Size can be up to $50 \%$ of the main ICU.

- Doctor/Patient ratio and Nurse/Patient ratio may be relaxed (1:2 and 1:3 respectively).

- It may also be used as palliative unit for patients who are terminally sick and for end of life care, if other area is not available for care of such patients in the hospital.

\section{Structure}

Location of ICU in Hospital ${ }^{9,13-26}$

- Safe, easy, fast transport of a critically sick patient should be priority in planning for location of ICU.

- Ground floor should be avoided for ICU location.

- First floor is the ideal location in close proximity of emergency and operation theater.

- Higher floors are suitable if elevators are available close to ICU.

- Corridors, lifts and ramps should be spacious enough to provide easy movement of bed/trolley (crisscross passage of two beds/ trolleys simultaneously)

- Close/easy proximity is also desirable to diagnostic facilities, blood bank, pharmacy, etc.

- There should be single entry/exit point to ICU and should be manned. Thoroughfare cannot be provided through ICU. However, it is required to have an emergency exit point.

\section{ICU Design ${ }^{13-26}$}

Dormitory-like ICU ${ }^{26,27}$

- Space per bed has been recommended from 150 to $200 \mathrm{sq} \mathrm{ft}$ in the patient care area. Some recommendations have placed it even higher up to $250 \mathrm{sq} \mathrm{ft}$ per bed. In addition, there should be 100 to $150 \%$ extra space to accommodate nursing station, storage, patient/doctors/staff movement area, equipment area, doctor's and nurse's rooms, teaching area, relative's area and toilets to include all the four zones of ICU.

- A buffer/bare area is desirable between relative's area and doctor's area.

- However, in Indian circumstances and, after reviewing and receiving feedback from various ICUs in our country, it may be satisfactory to suggest an area of at least 150 square feet per bed be provided in patient care area (Zone 1) for comfortable working with a critically sick patient where all the paraphernalia including monitoring systems, ventilators and other machines like bedside X-ray, ultrasounds, etc. and bedside procedures like central lines, intubation, tracheotomy, ICD insertion and RRT are common and require good space.

Single accommodation cubicles/rooms ${ }^{26-27}$

- Patient care area should be 200 to $250 \mathrm{sq} f \mathrm{ft}$. It may be prudent to make one or two bigger rooms or areas, depending upon needs like for bariatric patients and bedside procedures e.g. ECMO, RRT etc.

- It is recommended to have $10 \%$ (one to two) isolation rooms where immunocompromised/infected patients may be treated. These rooms should have $20 \%$ extra space. Need for lamellar flow in isolation room in ICU has not found favor.

Partition between two rooms/cubicles/beds ${ }^{27,31}$

- It is recommended that there should be a partition between rooms for patient's privacy.

- Standard curtains soften the look and are placed commonly between two patients in most Indian ICUs, however, curtains may become unclean or get displaced and breach the privacy.

- Two rooms may be separated by unbreakable fixed or removable partition which may be of aluminum, wood or fiber. However permanent partitions may take away the flexibility of increasing floor space temporarily when required.

Isolation rooms (Positive and negative pressure $)^{28-30}$

- To provide protective environment for patients at highest risk of infection, e.g. neutropenic and post-transplant. These rooms should have greater supply of air than exhaust air.

- Pressure differential of 2.5 -8 Pka, preferably 8 Pka. Positive airflow relative to the corridor (i.e. air flows from the room to the outside adjacent space).

- HEPA filtration is required in solid organ and hemopoietic cell transplant patients only.

Number of ICU Beds and ICUs in a Hospital ${ }^{31-35}$

- Brainstorming sessions should be held to decide how many ICUs and ICU beds are needed for the hospital. It should also discuss on need for HDU, PICU and specialty ICU like neuro, cardiac and trauma ilntensive care

- The number of ICU beds requirement depends on the hospital's total bed strength, available need assessment data and future requirement.

- Various issues like available space, trained manpower and budget are also important factor for consideration in deciding number of ICUs and ICU beds.

- In a tertiary care hospital, number of ICU beds requirement may vary from 5 to $25 \%$ of the total hospital beds according to the focus of the hospital. However, it is recommended that the number of ICU beds in any hospitals should not be less than $5 \%$ of total hospital beds.

- ICUs having $<6$ beds are not cost-effective and may not provide enough clinical experience and exposure to staff of the ICU. At the same time ICU with bed strength of $>12$ are difficult to manage. Recommendations suggest that efficiency may be compromised once total number of beds crosses 12 in ICU.

- It is recommended that total bed strength of ICU should be between 8 and 12. To have more ICU beds, it is recommended that number of ICUs be increased rather than increasing 
numbers of beds in one ICU. In required situations, ICUs with lesser or a greater number of beds may be created.

- The Canadian Department of National Health and Welfare has developed a formula for calculating the number of ICU beds required based on the average census in the existing unit and the desired probability of having an ICU bed immediately available for a new admission.

\section{Zones of $I C U^{36,37}$}

ICU area can be categorized into 4 different zones:

Zone 1: Patient care zone

Zone 2: Observation area

Zone 3: Support area

Zone 4: Family support zone

Patient care zone (Zone 1) ${ }^{15-26,36-38}$

It includes the area around patient's bed.

\section{Pendant vs Head-end panel ${ }^{15-26,36,37}$}

- One of the most important decisions is how to plan bedside design.

- Two approaches are usually practiced [head-end wall panel or free-standing/hanging systems (power columns) usually from the ceiling]. Each can be fixed or moveable and flexible. It can be on one or either side of the patient.

- Flexibility is usually desirable. Panels on head wall systems do not allow for free movements on the head end of the patients because of hanging wires and tubes.

- Though the hanging pendants look much more scientific, but our survey indicates most of our ICUs in India have head-end panels. However, new ICU planners may give a critical look at pendants rather than head-end panels.

- Adaptable power columns can move from side to side or rotate. Mounts on power columns are also usually adjustable.

- Flexible systems are expensive and counterproductive if the staff never move or adjust them.

- Ceiling-mounted, moveable, rotatory systems may reduce clutter on the floor and make a lot of workspace available. However, this may not be possible if the weight of the power column cannot be structurally supported.

- A usual problem observed in ICU is getting access to the head of the bed in times of emergency and therefore keep bed 2 feet away from head-end wall. This can be achieved effectively by placing a $2 \mathrm{ft}$ wide, 6 inches high wooden plank between the wall and head end.

- Lines may be routed through a fixed band.

Height of monitoring system ${ }^{15-26}$

- Monitoring system should be placed at the eye level. Doctors and nurses may have chronic head tilting leading to cervical neck discomfort and disorders otherwise.

\section{Observation area (Zone 2)}

- It includes central nursing station, nursing and doctor's station/ computer area/immediate investigation area like ABG analysis/ drug trolleys, chairs and other support system needed at the nursing station.

\section{Central nursing station (CNS) ${ }^{15-26,36}$}

- This is the nerve center of ICU, despite lots of development, the old standard of a central station still holds good and is endorsed by most guidelines and regulations regardless of today's practice needs.

- It is the station where all the resident doctors, nurses and other support staff come together to share information and keep records. All computers and digital information system, stationery material, registers, etc. are kept here. It provides moments of discussion, relaxation and center of administration.

- All/near-all monitors and patients must be observable from there, either directly or through the central monitoring system. Most ICUs use the central station, serving six to twelve beds arranged in an $L$ or $U$ fashion. Patients in rooms may be difficult to observe and therefore should be placed on remote television monitoring. These monitors may satisfy regulatory requirements but do not really provide adequate patient safety if the clarity of the picture is poor.

- Some ICUs have unit pods of about four or five beds, each served by a separate workstation, nurses assigned to patients in the pod form a team, a monitor technician is also required. The unit nursing clerk and the supervising nurse will usually work together to oversee the efficient interaction among the staff and with support services, Careful consideration of what level or type of activity will occur in the CNS will ensure adequate space planning, also, new equipment purchased over the next decade will probably increase the amount of desk and shelf space required.

- At times of high use, the number of people in the central station can increase several folds. Having enough space and chairs to meet needs during such times should be provided for. The space should accommodate computer terminals and printers. A large number of communication cables may be required per bedside to connect computers and faxes to other departments, as well as to other institutions and offices, adequate space for charting on the platform is absolutely important.

- Patients must be easily visible from the charting area whether the nurse is sitting or standing, taller chairs are often necessary. In case of space constraint, collapsible desktops or shelves that can flip up off the wall can be planned. Space allotted for storage of the previous charts of patients currently in the unit should also be provided It is also important that a storage space is provided for equipment, linen, instruments, drugs, medicines, disposables, stationery and other articles to be stored at the nursing station must be provided. All these cupboards should be labeled. The latest generation of monitoring systems allows access to patient data from any bedside; this means that the doctor who is busy caring for one patient can monitor others without leaving that bedside. Consoles can be programmed to automatically display critical events from one bedside at several sites without personnel calling for it.

- CNS has in-charge nursing, duty doctor (s), clerk, computer operator, machines, store attached and monitors and spare machines/spares, linen and other ancillaries.

Support area (Zone 3) ) $^{15-26,36-42}$

It includes offices, doctor's duty room, nurses' room, stores, toilets, discussion and teaching rooms including library.

Stores $^{15-26}$

- Four important store levels are recommended in a busy ICU.

- By the bedside/a portable trolley

- At the nursing station 
- Nursing stores

- Remote central store

- Those items used repeatedly and in emergencies should be readily available and easy to access. Storage of large inventory can be costly and also waste of personnel time. Making items more easily available may increase their use. Some overcautious or clever staff may decide to hoard or hide them. Cost-effective and efficient designs are needed.

- Staff nurses can always give useful ideas about improvement of systems, which they develop while working with patients. Their opinion can be invaluable.

- When medications are kept at the bedside, Joint Commission International $(\mathrm{JCl})$ currently requires that the storage be lockable, these stores can store medicines, disposables, records, injections, tabs, etc.

- Bedside supply carts that are stocked for different subsets of patients can make storage in the room more efficient, e.g. surgical, medical, trauma, and cardiac patients where needs are different.

- Staff nurses may be specifically trained for such care and work determining what supplies are placed near but not at the bedside is based on the size of the unit, the grouping of patients and the patterns of practice, although many units organize supplies by the department that restocks them (central services, nutrition, pharmacy, respiratory therapy, etc.).

- It is worth considering grouping supply by activity, like chest tray, central line tray, skin care tray, catheterization tray, intracranial pressure tray, etc.

Library $^{39}$

- $\quad$ Every ICU must have access to adequate number of books related to critical care medicine and related specialties, few relevant journals both for doctors and nurses. E-library is a must. However, books and journals in physical form are always preferred.

- The library should be interconnected with central library of the hospital.

Family support and remote area ${ }^{42}$

- It includes waiting area, relaxation area, prayer area, food, beverages, water, rest rooms, pharmacy and social workers area/counseling area/ICU central stores.

Floor, Wall and Ceiling Coverings ${ }^{15-26,40-43}$

Floor

- The ideal floor should be easy to clean, non-slippery, able to withstand abuse and absorb sound while enhancing the overall look and feel of the environment, carts and beds equipped with large wheels should roll easily over it.

- In Indian context vitrified non-slippery tiles seem to be the best option which can be fitted into reasonable budgets, easy to clean and move on and may be stain-proof Vinyl sheeting is another viable option, it can be nonporous, strong and easy to clean.

- The life of Vinyl flooring is not long and a small damage in one corner may trigger damage of entire flooring and make it accident-prone. It may require frequent replacement making it to be inconvenient choice.

Walls

- Durability, ability to clean and maintain, flame retardance, mildew resistance, sound absorption and visual appeal are the major requirements.
- It has been very useful to have a height up to 4 to 5 feet finished with similar tiles as of floor for similar reasons. For rest of the wall soothing paint with glass panels on the head end at the top may be good choice.

- Wooden paneling has also found favor with some architects, but costs may go high.

- Door stoppers and handrails should be placed well to reduce abuse and noise to minimum; it helps patient movement and ambulation.

Ceiling

- Ceiling surface is most commonly seen by patient. Bright spotlights or fluorescent lights can cause eye strain, ceiling should be soiling and break-proof due to leaks and condensation.

- Tiles may not be the most appealing or soothing surface, but for all practical purposes, it is easier to remove individual or few tiles for repairs over ceiling in times of need.

- Ceiling design may be enhanced by varying the ceiling height, softening the contours, griddled lighting surfaces, painting it with a medley of soft colors (yellow, sky-blue, light grey) rather than a plain background color, or decorating it with patterns or murals, to make it more patient- and staff-friendly.

- It is recommended that no lines or wires be kept or run over ceiling or underground because damages do occur once in a while and, therefore, it should be easy to do repairs if the lines and pipes are easily explorable without hindering patient care.

Furniture and Furnishings ${ }^{15-26,40-43}$

- The counters and furniture should be tough to withstand a lot of heavy use, easy to clean and maintain, connections should be made of metal to metal fasteners.

- Cabinet-quality wood construction should also be tough and strong, surfaces for counters should be solid, nonporous and stain-resistant, fabrics should be durable, color fast and flameand static-resistant, if possible.

- Bedside clocks, calendars and bulletin boards help the conscious patient to get well-oriented and in better moods.

- Providing the patient with a place to keep a few small personal items of their own make the environment more familiar and personalized.

- Some finishing touch like some artwork/décor/sculpture may change the ICU atmosphere a great deal and has been recommended by the ISCCM.

- Chair number and types: Individual units should decide about the number, usually enough number to accommodate the care-giving staff/doctors and nurses and additional chairs may be stored and used whenever needed. Individual units should decide whether they want to allow the relative to sit by the side (short or long time) of the patient in the ICU. However, a chair/sofa- type chair on wheels with safety belt or vault is recommended for mobilizing the patient and making him sit during recovery.

Electrical Services ${ }^{15-26,42-44}$

- The main electrical circuit breaker panel should branch out to individual feeder line for each ICU.

- The emergency power source like electricity generator power should quickly take over in case of city power failure.

- Each patient cubicle should have at least seven duplex grounded receptacles 5/15 amp as per AIA guidelines. The location of these receptacles can be either on wall, bed head 
panel, ceiling-suspended pendant units or vertical column based on choice from hospital team.

- It is strongly suggested to have at least 50 per cent of electrical receptacles connected to uninterrupted power supply (UPS) with proper label. Each receptacle or cluster within an ICU should be serviced by its own circuit breaker in the electrical panel preferably located in utility room of ICU.

- It is desirable that ICU is on uninterrupted power supply (UPS), if not, then, at least, 4 UPS points should be there on each panel and enough number of lights/computers to be on UPS.

- The lighting distribution illumination control should be planned based on routine physical examination (around 350 lux), during procedure of patient (around 1000 lux), during nighttime (around 5 lux). The lighting distribution board should be separate from power distribution board. The emergency lighting should be connected to few light fixtures to avoid a complete black out scenario. The energy conservation aspect like LED lights and more natural daylight should also be considered. $^{44}$

Environmental Requirements ${ }^{15-26,40-44}$

Heating, ventilation and air-conditioning (HVAC) system of $\mathrm{ICU}^{15-26}$

- The ICU should be fully air-conditioned which allows control of temperature, humidity and air change. If this may not be possible, then one should have windows which can be opened ('Tilt and turn' windows are a useful design). Suitable and safe air quality must be maintained at all times.

- Air movement should always be from clean to dirty areas. It is recommended to have a minimum of six air changes per room per hour, out of which two air changes per hour composed of outside air. Where air-conditioning is not universal, cubicles should have fifteen air changes per hour and other patient areas at least three per hour. The dirty utility, sluice and laboratory need five changes per hour, but two per hour are sufficient for other staff areas.

- In negative pressure isolation rooms (isolation of patients infected/suspected to be infected with organisms spread via airborne droplet nuclei $<5 \mu \mathrm{m}$ in diameter), the windows do not open. They have greater exhaust than supply air volume. Pressure differential of 2.5 Pa. Clean to dirty airflow, i.e. direction of the airflow is from the outside adjacent space (i.e. corridor, anteroom) into the room. Air from room preferably exhausted to the outside but may be re-circulated provided it is through HEPA filter. NB: re-circulating air taken from areas intended to isolate a patient with TB is a risk not worth taking and is not recommended.

- Central air-conditioning systems and re-circulated air must pass through appropriate filters. It is recommended that all air should be filtered to $99 \%$ efficiency down to 5 microns. Smoking should not be allowed in the ICU complex.

- Heating should be provided with an emphasis on the comfort of the patients and the ICU personnel. For critical care units having enclosed patient modules, the temperature should be adjustable within each module to allow a choice of temperatures from 16 to 25 degree Celsius.

- A few cubicles may have a choice of positive or negative operating pressures (relative to the open area). Cubicles usually act as isolation facilities, and their lobby areas must be appropriately ventilated in line with the function of an isolation area (i.e. pressure must lie between that in the multibed area and the side ward).

- Power backup in ICU is a serious issue. The ICU should have its own power backup, which should start automatically in the event of a power failure. This power should be sufficient to maintain temperature and run the ICU equipment (even though most of the essential ICU equipment have a battery backup). Voltage stabilization is also mandatory. An uninterrupted power supply (UPS) system is preferred for the ICU.

Lighting $^{15-26,43-45}$

- Access to outside natural light is recommended by regulatory authorities in USA. This may improve the staff morale and patient outcome.

- Data suggests that synthetic artificial daylight use in work environment may deliver better results for nighttime workers. It may be helpful in maintaining the circadian rhythm.

- Natural lighting in the unit can decrease power consumption and the electrical bill which is so relevant to Indian circumstances. Access to natural light also means one may have access to viewing external environment which may be developed into green and soothing.

- $\quad$ Light for procedures: High illumination and spot lighting is needed for procedures, like inserting central lines, etc. They can descend from the ceiling, extend from the wall/panel, or be carried into the room. Spot lighting should be shadow free with 150 footcandles $(\mathrm{fc})$ strength.

- Light required for general patient care should be bright enough to ensure adequate vision without eye strain.

- Overhead lighting should be at least 20 footcandles.

- Higher frequency fluorescent lights and coated phosphorus lamps may be good for assessing skin color and tone

- Patients may need rest and quiet surroundings during the day, blackout curtains or blinds or individual eye may be used. This may be helpful when the staff requires a high level of lighting at the bedside while the patient is resting.

- Lights that come on automatically when cupboard doors or drawers are opened are useful.

- Floors lighting may be important for safety at the bedside and in the hallways at night and should be about $10 \mathrm{fc}$. Glare created by reflected light should be diffused.

- Light switches should be strategically located to allow some patient control and adequate staff convenience.

- A second remote control can be turned on/off by the nurses/ doctors to observe patients intermittently at night without entering the room and disturbing the patient. Hall lights controls should be subdivided into smaller independent areas and dimmer switches may be desirable The Illuminating Engineering Society of North America published useful guidelines on this. Dull blue lights at night help good sleep and outcome of patients.

Noise level in $\mathrm{ICU}^{46-48}$

- The International Noise Council recommends that the noise level in an ICU be under $45 \mathrm{dBA}$ in the daytime, $40 \mathrm{dBA}$ in the evening and $20 \mathrm{dBA}$ at night. For example, $16 \mathrm{~A}$ watch ticks at about $20 \mathrm{dBA}$, normal conversation is at about $55 \mathrm{dBA}$, vacuum cleaner produces about $70 \mathrm{dBA}$.

\section{Equipment in the Intensive Care Unit}

- Equipment in the ICU include those movable items which are directly or indirectly required for the care and management 
of the critically ill patients. These range from large equipment like ventilators and ultrasound machines to small items like a thermometer. These items should be durable and easily portable (never fixed) to facilitate cleaning and disinfection of the surrounding area and the equipment itself.

- Increasingly, ICU equipment are being available as disposable, single-patient use items, which should be preferred especially for prevention of cross infection if cost-effective. While opting for disposable equipment, one should take into account not only the cost of the re-useable equipment, but that of sterilization, time, manpower, extra numbers required, storage space, etc. also. Examples of such items are bedpans, thermometer, flexible bronchoscopes, etc.

- Essential equipment is the minimum basic equipment required for the effective and safe functioning of the ICU. While desirable equipment is that which will further enhance the functioning of the ICU in terms of patient management and quality of care. We have further classified the essential equipment required in the $I C U$, along with the minimum and desirable quantity required, into the following categories:

- ICU furniture

- Equipment around the patient bed area/cubicle

- Equipment within the ICU

- We have enumerated only the reusable equipment in the ICU and broadly divided it into essential and desirable equipment (Annexure I).

\section{Considerations While Selecting and Purchasing Equipment for the ICU ${ }^{1,2,6,9,49,53}$}

- A continuously updated selection policy should be applied with medical, nursing and other concerned ICU staff to give suggestions and feedback on any new equipment required and also on the existing equipment in the ICU. This may avoid poorly considered last minute equipment selections.

- Technical advice and end user feedback should be sought from the hospital biomedical engineers, end users and from other departments within the hospital/other hospitals having similar equipment, who may be able to advise on the performance and service of the equipment.

- In addition to cost, end user comfort, storage space required, compatibility with existing equipment, compatibility for upgradation, sterilization compatibility with the existing hospital policy, maintenance requirements and service record of the vendor should be considered before purchasing equipment.

- Several equipment is now offered at no cost for commitment of purchase of a minimum number of associated disposable items over a specified period of time so this option should be considered.

- The advantages of bulk purchase with allied departments and purchase of similar equipment from the same vendor should also be considered. For example, selecting the same ventilator model from one company. This not only reduces cost but also will make it easy for the end user with uniform equipment, in terms of training and utilization and in addition similar equipment will be available for temporary use in case any equipment malfunction.

\section{Maintenance of ICU Equipment}

- A policy for maintenance of equipment in ICU is of utmost importance considering the number of users, uses, wear and tear of the equipment in a busy, highly stressed area such as the ICU.

- A culture of responsible utilization of equipment with accountability, from all end users, should be inculcated in the unit.

- Designated staff should be assigned, with accountability for the proper maintenance, including sterilization/disinfection, calibration and regular servicing of the equipment, to improve its life and thereby save on the cost of frequent replacement and repair.

\section{List of essential equipment ${ }^{1,2,6,9,49-53}$}

Annexure I - List of Equipment

Annexure II - Desirable Equipment

Annexure III - Recommended Bedside Standards for Each ICU Bed for Different ICU Levels

\section{Services}

\section{Definitions}

Intensive /Critical care ${ }^{1-9,14}$

- The terms Critical Care /Intensive Care/Intensive Therapy are synonyms and can be described as multidisciplinary, focused medical care for patients who have potentially recoverable/ lethal organ dysfunction of one or many organs of the body requiring intense observation and management by a specialized trained team of healthcare professionals including doctors, nurses and other support staff in a well-defined area/ space equipped with special medical gazettes and equipment.

- Critical Care Medicine is now recognized as a separate superspecialty. Most professional bodies and Critical Care Medicine Societies across the world have well-structured training programs in critical care and award separate degrees/diploma/ certificates. Therefore, it is an independent department in each hospital with its own professional and administrative structure. In India, National Medical Commission (NMC) and National Board of Education (NBE) run post-doctoral DM and DNB program respectively. Similarly, ISCCM conducts courses such as IDCCM, IFCCM, CTCCM and IDCCN for doctors and nurses through well-structured program.

- In addition, most super-specialties also provide training in critical care medicine in their respective areas like pulmonary and critical care, neurocritical care, organ transplantation critical care, cardiac critical care, Gl and hepatology, pediatric intensive care, etc.

\section{Intensivist or Critical Care Specialist ${ }^{54,55}$}

Following should be considered for being an Intensivist:

- Intensivist is a medical professional trained in intensive or critical care medicine according to the standards set by regulatory bodies. He/she ideally should work full time in ICU and spend at least $50 \%$ time of professional practice in ICU. He can be DM, DNB, FNB, PDCC, IFCCM or IDCCM. These qualifications in critical care are offered by $\mathrm{MCl}$, National Board of Examination and ISCCM, respectively, and also equivalent international professional training/qualifications in critical care recognized by $\mathrm{MCl} / \mathrm{NMC}$.

- Professionals trained in super-specialties of pulmonary and critical care medicine, anesthesia organ transplantation and critical care, or other super-specialties, working more 
than $50 \%$ of their professional time in critical care medicine (multidisciplinary ICU) be considered Intensivist. Those working only in their super-specialty are considered Intensivist for that subspecialty.

- There are good number of highly motivated self-trained Intensivists in India and other countries who have promoted and helped development of Critical Care Medicine. They have largely overviewed the curriculum setting up of above courses run by $\mathrm{MCl}$, National Board or ISCCM, they are existing teachers, guides, examiners for the all above mentioned courses. They hold the position of grandfathers in the specialty without holding any of the abovementioned degrees or diplomas like DM, FNB or IFCCM, because of non-existence of these degrees/ training when they followed and were trained in this specialty.

- Medical professionals having postgraduate degree in anesthesiology, internal medicine, emergency medicine, respiratory medicine, general surgery and pediatrics with more than 10 years of experience in intensive care.

- Medical professionals trained, certified by professional bodies in critical care (national/international) and working in critical care units for more than 15 years after graduation.

- Intensivist preferably should be administrative head of Intensive Care taking/guiding clinical decisions and actively participating in organization, coordination, planning, policy, academics and research. He/she should provide leadership.

\section{Closed vs Open ICUs ${ }^{54-62}$}

- In modern era, critical care medicine has become advanced. It requires dedication, commitment and focused approach. A fulltime Intensivist and his/her team offer better, structured and protocolized management to the critically sick patient. Most studies demonstrate positive impact of Intensivist-led ICUs.

- ISCCM constituted a committee on the above subject which published its opinion and recommendations in Indian Journal of Critical Care Medicine in 2006. They endorsed above view. Such Intensivist-led ICU labeled as Closed ICU.

- It is recommended that over a period of time the concept of Open ICU should go in favor of Closed ICUs.

\section{Initial Planning}

- Team formation and leader/coordinator nomination

- Data collection and analysis

- Beginning of the process and decide about budget allocation

- Aims and objectives

- Location, space, facilities

- Planning level of ICU care: Level I, II, III or tertiary care unit

- Number of beds and number of ICUs as needed for the institution

- Designing each bed layout and providing optimum space

- Modulation according to various types of space availability

- Free-hanging power columns vs head-end panel facilities

- Central nursing station designing

\section{Team Consists of the Following ${ }^{63,64}$}

- Intensivist

- Administrator

- Finance officer

- Architect and biomedical engineer

- Nursing officer
- Support staff

- Fire safety officer

- Microbiologist for infection control

- Any other person if is relevant

Who should Coordinate/Lead the Planning Team ${ }^{60}$

- Intensivist/In-charge is best suited to be the Coordinator

- He has technical skill and knowledge to plan and guide

- He will prevent mistakes to bare minimum

- He can suggest changes during the development phase itself if need be

- In some setups (particularly public sector) hospital's administrators are usually the coordinators of such project implementation process, as they can coordinate with all the major groups whose inputs/help are needed in achieving the target in time and quality. It may be difficult for intensivist to spare so much of time needed and coordinate with others.

\section{Human resource for ICU ${ }^{63-69}$}

- Human resource management is one of the most important components of the whole program. Healthcare staff required for ICUs should be dedicated, highly motivated, ready to work in stressful situations for long period. Various categories of adequately trained healthcare providers in their respective fields required in good ICU are:

- Intensivist or critical care specialist

- Resident/junior doctors

- Nursing officers and managers

- Respiratory therapist

- Physiotherapist

- Nutritionist

- Clinical pharmacist

- Technicians

- Computer programmer and data entry operator

- Biomedical engineer

- Social worker

- Counselor (medical psychology background)

- Other support staff including security personnel

Resident Doctors (NMC/NBE Endorsed) ${ }^{65-69}$

- Postgraduates from anesthesia, medicine or respiratory medicine or other allied branches like pediatrics even surgical specialties may be posted as resident doctor. Other resident may be graduates depending upon total bed strength of ICU.

- Though need of resident doctors for number of patients has not been prescribed in literature; however, it is understood and recommended that one doctor cannot take care of more than five patients who are critically sick. Therefore, it is suggested that one postgraduate resident with one graduate resident may be good for an ICU of 10 to 12 beds.

Nursing staff (INC or other regulatory body endorsedpreferably IDCCN) $63,64,68-76$

- Nurses are key to success of any ICU. Therefore, utmost care should be taken in their numbers, qualification, training, motivation and prevent burn out. One to one nurse for ventilated or MODS patients are desirable but in no circumstance the ratio should be less than 2:3 (2 nurses for 3 patients). This will affect the outcome immensely.1:2 to 1:3 nurse 
patient ratio is acceptable for less seriously sick patients who do not require above modalities.

- Number of nurses should include provision for leave, offs and sudden dropouts. It is very important to motivate these nurses regularly both in terms of financial incentives and good working environment in view of very high attrition rates.

- Replacement/transfer should not be more than $20 \%$ per annum of the ICU nurses.

\section{Supportive Staff $63,64,68,69$}

- $\quad$ Respiratory Therapist (RT): RT looks after the patients being ventilated. They monitor as well as adjust ventilator parameters under supervision.

- Physiotherapist (PT): PT helps in mobilization and chest clearance. It has been proven that regular physiotherapy of patients particularly in neurologically affected patients, outcome is markedly improved, and this takes away lot of load off the duty doctor and the nurses. Occupational therapist if available is good for ICU

- Technicians: Person qualified to perform simple procedures like taking various investigative samples and sending them to proper place in proper manner makes the task easy and less stressful. Renal Replacement Technician should be there in all level 2 or 3 ICUs

- Computer operator and data entry operator: They can prepare reports, enter data and bring out printouts as and when needed. They also help in analyzing the data. They can also maintain library, Internet and protocols practiced in ICU. Research, data collection and integration, documentation and record keeping are also important components.

- Biomedical engineer: Biomedical engineer makes job of ICU less frustrating when snags creep in within sensitive ICU equipment. $\mathrm{He} /$ she can repair them fast and provide maintenance service for smooth functioning of equipments.

- Nutritionist: Nutritionist in ICU is also a very important professional who can contribute to outcome of patient. They have to be trained in desired practices and should be more inclined towards enteral feeding than total parenteral nutrition. Nutritionist should be well versed with local foods.

- House-keeping staff: They are also important to ICU particularly when they understand needs of ICU and its patients. They have a huge role to play in prevention of nosocomial infection, keeping ICU clean and protected from overcrowding. One person should be responsible for observing protocols of pollution and infection control. Housekeeping is often overlooked. Such staff with long-term exposure to ICU culture and requirement are very handy and they know what is where, what is next, nomenclature of equipment and sensitive of actions in ICU. Therefore, they form very important part of the team. In additions the ICU should be ably supported by clinical laboratory staff, microbiology and imaging staff who can understand the protocols of ICUs and act within discipline.

- Security guards: They are trained to have good attitudes and regulate crowd of visitors particularly in our country. Increasingly, they are expected to play significant role to play in prevention of physical violence by relatives of patients and political activists. The role of able well-built, trained guards yet modest in behavior in routine circumstances, cannot be overemphasized.
- Medical social worker: Medical social worker and counselor will ease the stress of family members, patients and healthcare professionals.

\section{Disaster Preparedness and safety issues ${ }^{77-79}$}

- Major disasters that have been reported during last two decades within India are:

- Fire

- Floods

- Breaking of central oxygen supply

- Major power failure

- A/C failure

- Human violence which include terrorist attack and violence by relatives/political activists of patients

- Infection breakouts

Fire $^{9,10,14,77,78}$

Fire has been major culprit and led to unacceptable injuries and deaths of patients, their relatives, doctors, nurses and other support staff. All ICUs should be designed to handle such disasters. Following precautions must be taken:

- Fire protection measures should be incorporated at the time of designing of ICU both preventing fire occurrence at all as also controlling fire spread.

- No ICU should be commissioned unless there is NOC from local municipal authorities

- Most deaths in ICUs occur because of suffocation rather than burns. Smoke spreads through the A/C ducts; therefore, as a rule $A C$ ducting of ICUs should not be connected to any other facility ducts at all.

- There should be adequate firefighting equipment inside ICU and protection from electrical defaults and accidents.

- A charter of Do's and Don'ts should be prominently displayed.

- Preventive maintenance of potential sensitive equipment and suspected short-circuiting elements should be carried out regularly and duly recorded. Ideally an all clearance certificate should be obtained from hospitals engineering department on regular intervals.

- Insertion of naked electric wires without male plugs is totally banned.

- Smoking, joss sticks (agarbattis), candles, or any ignitable substance, mobile charging, repair by welding should be completely banned in ICU.

- The glass panels on ICU window should be breakable with hammers. Such hammers should be put and displayed in glass cupboards which can easily obtained. Guide for methods to open the windows should be put up under each window in local language.

- Regular updating, exercise and mock drill should be conducted.

- Exit and escape routes signage should be displayed in local languages at prominent points near the ICU.

- The floor, walls, furniture, cupboards, beds, etc. should be as much fireproof as possible

- There must be an emergency exit and staircase for ICU to rescue patients in times of internal disaster.

- There should be provision for some contingency room within hospital where critically sick patients may be shifted temporarily. HDU may be the best place if beds are vacant. 


\section{Floods $9,10,14$}

- In India flood is common during rainy seasons in some area hence ICU should be located preferably on higher floor and provision for water drainage should be made. Such disasters have been reported in India from ICUs.

\section{Oxygen Failure $9,10,14$}

- There have been reports of multiple deaths in Indian ICUs because of central oxygen supply failure. This can be prevented by making provision of alternative supply line of oxygen using oxygen cylinder of different capacity as per requirement. Functional status of these cylinders must be checked periodically.

Power Failure $9,10,14$

- Alternative power supply in the form of source UPS $(24 \times 7)$ for all beds, possibly whole ICU must be available

Air-conditioning Failure 9 , 10, 14-26

- Temperature control in ICU is also an important issue and need to be addressed. Alternative source of power supply in the form of generator must be available.

\section{Public Violence ${ }^{1-9}$}

- Various factors are responsible for public violence in critical care settings and following measures may be taken to prevent the violence:

- Good buffer zone may be created between public and ICU staff

- Counselor to address the issues

- Frequent update on patient condition

- Written and displayed hospital policy

- No hidden agenda

- Well-trained guards $(24 \times 7)$ to control the situation

- Frequent interaction with relatives.

Infection Prevention 9, 10, 14, 79

- ICU is vulnerable area for spread of Infection; therefore, it is imperative that all protocols and recommendation practices about infection control and prevention are observed and if there is a breakout then adequate steps taken to control this and disinfect the ICU if indicated.

- Infection control practices must be in top of the priority list of every ICU.

- All the Recommendations of State Pollution Control Boards and Biomedical Waste guidelines must be followed in letter and spirit.

- All beds must have $24 \times 7$ Hand rub solution bottle hanging by the bed foot end or around

- There should be one handwash basin with elbow operated water tap for at least 5 beds. A handwash basin for every bed may require lot of space and may lead additional problems.

- All linen/equipment used in ICU procedure should be sterilized by autoclave or any other standard methods

- Dedicated ICU autoclave/ETO rooms are desirable for larger ICUs

- Standard methods/protocols should be adopted to dispose off single use disposable tubes/catheters and lines and should be transported out of ICU either by dedicated ducts or by closed cart.

- Regular fumigation of ICUs is neither possible nor desirable. However, floor moppings, equipment cleaning solutions and cleaning of beds are strongly recommended

- No dirty/soiled linen/material should be allowed to stay in ICU for long times for fear of spread of bad odor, infection and should be disposed off as fast as possible. Dirty linen should be replaced regularly at fixed intervals. All surroundings of ICU should be kept absolutely clean and green if possible.

\section{Facilities $^{9,10,14-26}$}

\section{Meeting the Needs of Healthcare Providers $9,10,14,42$}

- There should be adequate space and facilities healthcare providers (discussion, relaxation, lectures, library, internet, refreshments, and rest room) and should be in close proximity to the unit so that a close observation may be done through glass.

- It is advisable to have separate changing room for nurses and doctors.

- Lockers may be provided to keep costly personal belongings.

Meeting the Needs of Relatives ${ }^{42}$

- Respecting the relatives, their needs and emotions and reacting with empathy may solve the concerns of family members. Frequent counseling by authorized healthcare provider and having some comfortable space (having washroom and facility of drinking water) close to ICU for waiting, meeting, rest area, addressing and some kind of stress relieving games or activities.

- Many guidelines suggest that I-I/2 to 2 seats per patient bed be provided in the waiting area. Depending on space available this may be designed.

- Facilities of cafeteria may be made available nearby for relaxation and discussion with each other. This will help in relieving the stress and anxiety.

\section{Water Supply and Sanitation 9 , 10, 14}

- Uninterrupted clean and sterile RO water at desirable temperatures must be supplied $24 \times 7$ to the doctors and nurses working in the ICU as well as to the relatives of the patients

- There should be enough number of toilets for doctors and nurses separately. Separate facility should be provided for males and females

- For doctors and nurses working on night duties, there should be provision for shower with running hot and cold water.

\section{Communication Area $^{42}$}

- A central communication area is also needed for unit, and hospital wide announcements; newsletters and memos: and announcements of outside events and meetings.

- Bulletin boards are necessary but often unsightly.

- It is better to plan them because they may be added after the fact in a less effective or appealing manner

Music, Mobile Phone and Alarms 9 , 10, 14, 46-48

- $\quad$ Since the noise level in ICUs have to kept between 20-45 dBA, each unit has to decide on this issue. 
Annexure I: List of Equipment

\begin{tabular}{|c|c|c|c|c|}
\hline S.N. & Name of Equipment & $\begin{array}{l}\text { Minimum } \\
\text { number }\end{array}$ & Desirable & Remarks \\
\hline 1. & ICU Bed with mattress & As per unit size & & $\begin{array}{l}\text { Electrically operated with remote control facility and having } \\
\text { minimum of following functions (back rest tilting } 0-70^{\circ} \text {, } \\
\text { knee rest tilting } 0-35^{\circ} \text {, Trendelenburg tilting } 0-12^{\circ} \text {, reverse } \\
\text { Trendelenburg tilting } 0-12^{\circ} \text { mattress base tilting to the } \\
\text { left up to } 22^{\circ} \text {, tilting to the right up to } 22^{\circ} \text { ). In built patient } \\
\text { weighing facility is desirable in Level III units. }\end{array}$ \\
\hline 2. & Air mattress & 2 & $\begin{array}{l}\text { One per bed in level II } \\
\text { \& III ICU }\end{array}$ & $\begin{array}{l}\text { Alternating air pressure and bubble technology will be } \\
\text { preferred. }\end{array}$ \\
\hline 3. & Over Bed table & 1 per bed & & $\begin{array}{l}\text { Having facility of height adjustment, swivel and lock } \\
\text { mechanism. }\end{array}$ \\
\hline 4. & Locker with table & 1 per bed & & Water proof and easy to clean \\
\hline 5. & Bedside chair/recliner & 1 per bed & & Oversize preferred \\
\hline 6. & Stretcher trolley & 1 per unit & $\begin{array}{l}\text { As many as required } \\
\text { (AMAR) }\end{array}$ & \\
\hline 7. & Wheelchair & 1 per unit & AMAR & $\begin{array}{l}\text { Spacious, washable with seat belt with provision for carrying } \\
\text { small oxygen cylinder and with big pocket }\end{array}$ \\
\hline 8. & $\begin{array}{l}\text { ICU chairs for staff and } \\
\text { relatives }\end{array}$ & 6 per unit & AMAR & \\
\hline 9. & Procedure trolley & 1 per unit & AMAR & $\begin{array}{l}\text { For drug preparation or performing any sterile bedside } \\
\text { procedures }\end{array}$ \\
\hline 10. & Emergency Crash Cart & 1 per unit & AMAR & $\begin{array}{l}\text { As per } \mathrm{JCl} / \mathrm{NABH} \text { specifications with all emergency drugs and } \\
\text { equipment }\end{array}$ \\
\hline 11. & Linen cart & 1 per unit & AMAR & Covered, separate for clean and dirty linen \\
\hline \multicolumn{5}{|c|}{ Bedside Equipments } \\
\hline 12. & ICU Ventilator & $\begin{array}{l}\text { Minimum } 2 \text { per } \\
\text { unit per unit }\end{array}$ & $50 \%$ of Beds number & $\begin{array}{l}\text { With all basic modes, advanced modes desirable } \\
\text { One Oscillator in desirable Level III }\end{array}$ \\
\hline 13. & NIV & $\begin{array}{l}\text { Minimum } \\
1 \text { per unit }\end{array}$ & $25 \%$ of beds & $\begin{array}{l}\text { Standard NIV machines with control FiO2 and TV, RR is } \\
\text { recommended, }\end{array}$ \\
\hline 14. & High flow Nasal cannula & 1 per unit & $\begin{array}{l}\text { One HFNC may be } \\
\text { desirable }\end{array}$ & Standard equipment \\
\hline 15. & Multiparameter monitor & 1 per bed & $\begin{array}{l}1 \text { per bed } \\
\text { Provision for stand- } \\
\text { bye In level II and III }\end{array}$ & $\begin{array}{l}\text { Displayed parameters should include non- invasive blood } \\
\text { pressure (NIBP), oxygen saturation }\left(\mathrm{SpO}_{2}\right) \text {, heart rate (HR) } \\
\text { respiratory rate (RR) and electrocardiogram waveform (ECG). } \\
\text { In Level II and Level III all monitors Should have provision } \\
\text { for invasive monitoring } 20 \% \text { Monitors should have Cardiac } \\
\text { output modules in Level II and III Temperature monitoring, } \\
\text { ETCO } \mathrm{C}_{2} \text { is desirable. High accuracy, simple light weight, large } \\
\text { high resolution color LCD screen should be preferred. }\end{array}$ \\
\hline 16. & Computer & 1 per unit & AMAR & $\begin{array}{l}\text { Individuals ICUs should decide about how much they want } \\
\text { ICU to be paperless }\end{array}$ \\
\hline 17. & Clock and calendar & 1 per unit & 1 per bed & Clock and calendar should be easily visible from each bed \\
\hline 18. & $\begin{array}{l}\text { Sequential compression } \\
\text { devices }\end{array}$ & 1 per unit & 1 per bed & $\begin{array}{l}\text { Intermittent pneumatic compression device with } 12 \text { second } \\
\text { inflation and } 48 \mathrm{~s} \text { deflation time. Display of delivery pressure } \\
\text { on device is desirable }\end{array}$ \\
\hline 19. & IV Drip stand/Support & 1 per bed & AMAR & $\begin{array}{l}\text { Stainless steel, No IV stand should be floor types, they should } \\
\text { be hanging from the ceiling on either side of the patient. } \\
\text { Drip Hangers in the middle of the bed are usually least used. } \\
\text { Dedicated stands (heavy duty) should be supported from } \\
\text { Corner ends of bed to hold and bear the weight of multiple } \\
\text { syringe pumps }\end{array}$ \\
\hline 20. & Syringe pumps & 1 per bed & AMAR & $\begin{array}{l}\text { Small, lightweight, portable device with pulseless flow with a } \\
\text { very high precision in delivery }\end{array}$ \\
\hline
\end{tabular}




\begin{tabular}{|c|c|c|c|c|}
\hline 21. & Infusion Pumps & 1 per unit & AMAR & $\begin{array}{l}\text { small, lightweight, portable device } \\
\text { Few online warming Infusion pumps should be available in } \\
\text { Level II and III units }\end{array}$ \\
\hline 22. & Feeding pump & Desirable & AMAR & Ambulatory volumetric pump \\
\hline 23. & Stethoscope & 1 per bed & 1 per bed & \\
\hline 24. & $\begin{array}{l}\text { AMBU bag with face } \\
\text { mask of Variable sizes }\end{array}$ & 1 per bed & 1 per bed & $\begin{array}{l}\text { One on each bedside under sterile cover. Ideally with a } \\
\text { reservoir bag. Provision for replacement units } \\
\text { Few Bain's circuit units are always handy }\end{array}$ \\
\hline 25. & Digital thermometer & 1 per bed & 1 per bed & Single patient uses only \\
\hline 26. & Torch & 1 per unit & 1 per bed & Focused light with spare batteries \\
\hline 27. & Reflex hammer & 1 per unit & 1 per bed & \\
\hline 28. & Surgical head light & 1 per unit & 1 per bed & Required for procedures \\
\hline 29. & Glucometer/ketometer & 1 per unit & 1 per bed & \\
\hline 30. & $\begin{array}{l}\text { Kidney tray of various } \\
\text { sizes }\end{array}$ & QS & QS & Disposable may be preferred. Single patient uses only \\
\hline 31. & $\begin{array}{l}\text { Biological waste bin } \\
\text { (Black and yellow, Blue } \\
\text { and Red bags) }\end{array}$ & 1 set per bed & 1set per bed & As per BMW Rules \\
\hline 32. & Pressure infusion bag & 1 per unit & 1 per bed & $\begin{array}{l}\text { Color-coded gauge pressure }(0-300 \mathrm{mmHg}) \text { preferable latex } \\
\text { free }\end{array}$ \\
\hline 33. & $\begin{array}{l}\text { Patient communication } \\
\text { devices }\end{array}$ & 1 per unit & 1 per bed & Ranging from alarm bell to advance interfaces \\
\hline \multicolumn{5}{|c|}{ Equipment within the unit } \\
\hline 34. & ABG machine & $\begin{array}{l}1 \text { per unit or in } \\
\text { hospital }\end{array}$ & & POC, simple to use, lab quality results \\
\hline 35. & ECG machine & 1 per unit & & $\begin{array}{l}\text { Meets IEC60601-2-51 international standard for digital } \\
\text { electrocardiographs specifying accuracy and digital filter } \\
\text { performance Compact and lightweight. LCD screen displays } \\
\text { simultaneous } 12 \text { lead EC }\end{array}$ \\
\hline 36. & Defibrillator & 1 per unit & AMAR & $\begin{array}{l}\text { Conventional defibrillator/ Automated external defibrillator } \\
\text { (Biphasic) } \\
\text { Bluetooth data transfer, and multi-parameter monitoring } \\
\text { including } 3,6,12 \text {-lead ECG, } \mathrm{SpO}_{2} \text {, temperature, and } \mathrm{ETCO}_{2} \text {, } \\
\text { IBP, temperature monitoring AED with disposable pad } \\
\text { adapter cable and disposable pads, automatic charging } \\
\text { starts for hands-free defibrillation, CPR timing sound, and } \\
\text { optional voice prompt }\end{array}$ \\
\hline 37. & $\begin{array}{l}\text { Pacemaker (transvenous) } \\
\text { Pacemaker TC }\end{array}$ & 1 per unit & AMAR & $\begin{array}{l}\text { Intuitive dial technology that allows for fast and easy access } \\
\text { to stimulation and sensitivity settings for the atrium and } \\
\text { ventricle. } \\
\text { Longer Battery Life }\end{array}$ \\
\hline 38. & $\begin{array}{l}\text { Temperature monitoring } \\
\& \text { Management tools }\end{array}$ & & & \\
\hline 39. & Cardiac output monitor & & AMAR & Non-invasive CO monitor is desirable in Level III \\
\hline 40. & $\begin{array}{l}\text { Portable Ultrasound } \\
\text { machine }\end{array}$ & $\begin{array}{l}\text { Available for } \\
\text { ICU use }\end{array}$ & & $\begin{array}{l}\text { Portable ultrasound scanner with ECHO facility -General } \\
\text { Description: General purpose portable ultrasound } \\
\text { scanner, with multiple focus electronic probes. 1. System } \\
\text { Specifications: PROBES: Electronic 3.5MHz convex Electronic } \\
7.5 \mathrm{MHz} \text { linear Scan Modes: B, M, B+M, B+B }\end{array}$ \\
\hline 41. & $\begin{array}{l}\text { Flexible Bronchoscope } \\
\text { (different diameter) }\end{array}$ & $\begin{array}{l}\text { Available for } \\
\text { ICU use }\end{array}$ & One & Mandatory for Level II and III ICU. \\
\hline 42. & Laryngoscope & 1 per unit & AMAR & $\begin{array}{l}\text { Adult and paediatric with all sizes and different shaped } \\
\text { blades and spare bulbs }\end{array}$ \\
\hline 43. & $\begin{array}{l}\text { ET and Tracheostomy } \\
\text { tubes (all sizes) }\end{array}$ & QS & & Disposable ET/TT tubes with Supra-glottic drain is preferred \\
\hline
\end{tabular}




\begin{tabular}{|c|c|c|c|c|}
\hline 44. & $\begin{array}{l}\text { PCT (All sizes) with } \\
\text { Supportive equipment }\end{array}$ & QS & & Standard tubes are recommended \\
\hline 45. & $\begin{array}{l}\text { Basic airway } \\
\text { management tools }\end{array}$ & $\begin{array}{l}\text { Available for } \\
\text { ICU use }\end{array}$ & AMAR & Stylet, boogies, LMA of all sizes and Combitube \\
\hline 46. & Test lung & 1 per unit & AMAR & Should be available with the ventilator \\
\hline 47. & $\begin{array}{l}\text { Cuff pressure } \\
\text { manometer }\end{array}$ & 1 per unit & AMAR & \\
\hline 48. & Potable $\mathrm{X}$ ray machine & $\begin{array}{l}\text { Available for } \\
\text { ICU use }\end{array}$ & & \\
\hline 49. & RRT & $\begin{array}{l}\text { Available in } \\
\text { hospital }\end{array}$ & $\begin{array}{l}\text { Should have } 20 \% \\
\text { beds having facility } \\
\text { for HD /SLEDD }\end{array}$ & HD, SLED machine/ CRRT machine, Plasmapheresis \\
\hline 50. & $\begin{array}{l}\text { Sterile trays with } \\
\text { instruments for various } \\
\text { procedures }\end{array}$ & 1 per unit & AMAR & $\begin{array}{l}\text { Sterile instruments for aiding ICU procedures like } \\
\text { tracheotomy, central line, arterial line, inter-costal drain, } \\
\text { pericardiocentesis, lumbar puncture/drain, epidural catheter, } \\
\text { bone marrow aspiration, intra-cranial drain, others catheters/ } \\
\text { drains and regional pain blocks. } \\
\text { The trolley should have a sterile supply of disposables } \\
\text { required. }\end{array}$ \\
\hline 51. & $\begin{array}{l}\text { Portable suction } \\
\text { machine }\end{array}$ & 1 per unit & AMAR & Fixed, battery operated, hand and foot operated \\
\hline 52. & Transport ventilator & 1 per unit & AMAR & MRI compatible ventilator should be available in hospital \\
\hline 53. & Transport monitor & 1 per unit & AMAR & $\begin{array}{l}\text { Lightweight, easy to carry and hook it onto a bedrail. Long- } \\
\text { time battery operation. MRI compatible monitor should be } \\
\text { available in hospital } \\
\text { Pulse oximeter should also be available separately in each } \\
\text { ICU. }\end{array}$ \\
\hline 54. & $\begin{array}{l}\text { Patient Cooling and } \\
\text { warming devices }\end{array}$ & Desired & AMR & $\begin{array}{l}\text { Disposable Cooling and heating devices are mandatory in } \\
\text { level II \& III }\end{array}$ \\
\hline 55. & Refrigerator & 1 per unit & AMAR & \\
\hline 56. & EEG, EMG and NCV & On demand & One per unit & Desirable to mandatory in level II and III respectively \\
\hline 57. & $\begin{array}{l}\text { Reusable cleaning } \\
\text { equipment }\end{array}$ & 1 per unit & AMAR & Mops, buckets etc. \\
\hline 58. & Ampoule cutter & AMR & AMAR & \\
\hline 59. & Sphygmomanometers & AMR & AMAR & \\
\hline 60. & Communication device & 1 per unit & AMAR & $\begin{array}{l}\text { Ranging from fixed telephone line/Intercom/ICU Mobile/Tele } \\
\text { ICU facility to Audio-visual recording in counselling areas }\end{array}$ \\
\hline 61. & Printer/xerox & 1 per unit & AMAR & Should be available at secretarial area in ICU \\
\hline 62. & X-ray view box & 1 per unit & AMAR & If PAC online system is not available \\
\hline 63. & $\begin{array}{l}\text { Radiation safety } \\
\text { equipment }\end{array}$ & $\begin{array}{l}\text { Available for } \\
\text { ICU use }\end{array}$ & 1 per unit & $\begin{array}{l}\text { As per radiation safety guidelines. Lead aprons, thyroid } \\
\text { shield, radiation monitoring and dosimeter badges as per } \\
\text { Atomic energy regulatory board (AERB)India }\end{array}$ \\
\hline 64. & Weighing scale & 1 per unit & 1 per unit & $\begin{array}{l}\text { It is desired that ALL ICU beds have patient weighing inbuilt } \\
\text { facility }\end{array}$ \\
\hline 65. & $\begin{array}{l}\text { Pads for prone } \\
\text { positioning }\end{array}$ & 1 set per unit & AMAR & Mandatory for Level II and Level III \\
\hline 66. & Tongue depressor & 1 per unit & AMAR & \\
\hline 67. & $\begin{array}{l}\text { ETO and Sterilization } \\
\text { support }\end{array}$ & Available & Should be $24 \times 7$ & Mandatory for Level II and III may be shared with OT facility \\
\hline 68. & ECMO & --- & One & Desirable for Level ii and mandatory for level III \\
\hline 69. & $\begin{array}{l}\text { Point of Care Tests } \\
\text {-Bedside Lactate, } \\
\text { Procalcitonin, ProBNP }\end{array}$ & Desirable & One per unit & Mandatory for Level II and Level III \\
\hline
\end{tabular}


Annexure II: List of Desirable Equipment

Desirable Equipments $1,2,6,9,49-53$

\begin{tabular}{|c|c|}
\hline Equipment & Specification \\
\hline IABP & Should be available to ICU as and when required \\
\hline ECMO equipment & Should be available to hospital as and when required \\
\hline TEE & Available in Hospital \\
\hline $\begin{array}{l}\text { EEG monitoring machine } \\
\text { Evoked potential,EMG and NCV }\end{array}$ & $\begin{array}{l}\text { Electroencephalograph- analyzer. Based on the personal computer. } \\
\text { Should be available to ICU as and when required }\end{array}$ \\
\hline BIS monitor & Should be available in hospital \\
\hline Patient elevation device/ bed rollers & Should be available in ICU \\
\hline Spirit Level & Should be available in ICU \\
\hline CPR Board & Optional / part of crash cart or Code blue bag \\
\hline $\begin{array}{l}\text { Spine boards } \\
\text { Scoop stretcher } \\
\text { Cervical immobilization devices } \\
\text { Patient transport board }\end{array}$ & $\begin{array}{l}\text { light weight, MRI compatible } \\
\text { Should be available in hospital }\end{array}$ \\
\hline Ultrasonic nebulisers & Should be available in ICU \\
\hline $\begin{array}{l}\text { Chest physiotherapy and airway clear- } \\
\text { ance devices }\end{array}$ & Should be available in hospital \\
\hline Braces and splints & As per patient needs \\
\hline Humidifier & Should be available in ICU with ventilator/NIV \\
\hline Vacuum cleaning machine & Should be available in hospital \\
\hline Body warming and cooling devices & Should be available in ICU \\
\hline Physio Tilt Table & $\begin{array}{l}\text { A special table for long term patients, including those on life-support, who need extensive } \\
\text { physiotherapy }\end{array}$ \\
\hline Fluid warming system & Should be available in ICU \\
\hline Bed weighing scale & Should be available in ICU \\
\hline ICP Monitor & Should be available in hospital \\
\hline CPR assist devices & Optional / part of crash cart or Code blue bag \\
\hline CPR meter & Optional / part of crash cart or Code blue bag \\
\hline Oxygen concentrator & Available in ICU \\
\hline HFNC device & Available in ICU \\
\hline Bed pan and urine container washer & Available in ICU \\
\hline IAP monitoring & Should be available in hospital \\
\hline Temprature and humidity sensor & Available in ICU \\
\hline $\begin{array}{l}\text { Cardiotocograph } \\
\text { Fetoscope and fetal Doppler }\end{array}$ & Should be available in hospital \\
\hline Shoe cover dispenser & Entry of ICU \\
\hline $\begin{array}{l}\text { Fundoscope } \\
\text { Endoscope }\end{array}$ & Should be available in hospital \\
\hline Videolaryngoscope & \\
\hline
\end{tabular}


ICU Design Indian Guideline(s) Draft

Annexure III: Recommended Bedside standards for each ICU Bed for different ICU levels - Birds eye view $1,2,6,9,49-53$

\begin{tabular}{|c|c|c|c|}
\hline Standards & Level 1 & Level II & Level 3 \\
\hline Oxygen outlets & 2 & 2 & 3 desirables \\
\hline Vacuum outlets & 1 & 1 to 2 & 2 \\
\hline Compressed air outlets & 1 & 1 to 2 & 2 \\
\hline $\begin{array}{l}\text { Electric outlets } \\
15 \text { amperes }\end{array}$ & 2 & 4 & 6 \\
\hline $\begin{array}{l}\text { Electric Outlets } \\
5 \text { amperes }\end{array}$ & 10 & 16 & 20 \\
\hline Infusion Pumps & Total 3 Pumps & 1 per bed & 3 Per bed with one warmer \\
\hline Syringe Pumps & 2 per bed & 3 per bed & $=/>4$ Per bed \\
\hline UPS & 2 Points & 3 to 4 points per bed & $\begin{array}{l}5 \text { points } \\
\text { mandatory, } 100 \% \text { desirable }\end{array}$ \\
\hline Unit Size & 6 to 8 beds & 10 to 12 beds & Multiple X 10 to 12 beds \\
\hline Bed space & 150 & 150 to 175 & 150 to 250 \\
\hline
\end{tabular}

UPS, uninterrupted power supply

\section{References}

1. CU Planning and Designing in India Guidelines 2010: $w w w . i s c c m . o r g$

2. ISCCM Survey 2018: website www.isccm.org

3. Levels of Critical Care for Adult Patients. Intensive care society standards $\odot 2009$

4. NIH Consensus Development Conference on Critical Care Medicine. As summarized in: Crit Care Med 1983; 11:466-69

5. Goldhill D. Levels of critical care for adult patients. Standards and guidelines2002. Intensive Care Society, London

6. Ferdinande $\mathrm{P}$, Memebers of The Task Force of the European Society of Intensive Care Medicine. Recommendations on minimal requirements for intensive care departments. Members of the Task Force of the European Society of Intensive Care Medicine. Intensive Care Med1997; 23:226-232

7. Guidelines for Categorization of Services for the Critically ill Patient. Critical Care Medicine 1991; 19(21):279-285

8. Haupt MT, Bekes CE, Brilli RJ, Carl LC, Gray AW, Jastremski MS, et al. Guidelines on critical care services and personnel: recommendations based on a system of categorization of three levels of care. Crit Care Med 2003;31:2677-2683

9. Andreas Valentin and Patrick Ferdinande (ESICM Working Group on Quality Improvement): Recommendations on basic requirements for intensive care units: structuraland organizational aspects Intensive Care Med 2011;1 37:1575-1587

10. MINIMUM STANDARDS FOR INTENSIVE CARE UNITS:College of Intensive Care Medicine of Australia and New Zealand: C-1 (2011)

11. Minimum standards for HDU - Policy document IC13 Melbourne Joint faculty of Intensive Care Medicine $2000 \mathrm{~s}$

12. Marshall JC, Bosco L, Adhikari NK, Connolly B, Diaz JV, Dorman T, et al. What is an intensive care unit? A report of the task force of the World Federation of Societies of Intensive and Critical Care Medicine. Journal of Critical Care 2017;37:270-276

13. M K Arora. Minimum standards for intensive care units to be adopted throughout the country. Vide memo F. No. 35-17/2012/ Ministry/ Co- ordination Cell/ Estt. I. dated May 24, 2012 issued at AlIMS, New Delhi. www.hp.gov.in/dhsrhp/ICU.pdf

14. The Joint Commission Accreditation Manual for Hospitals, Special Care Units Section. Joint Commission on Accreditation of Healthcare Organizations, Chicago, IL, 1990.

15. Hamilton D, Shepley M: Design for Critical Care: An Evidence-based Design Approach. Oxford, UK, Architectural Press/Elsevier, 2010

16. Society of Critical Care Medicine (SCCM), American Association of Critical Care Nurses (AACN), and American Institute of Architects (AIA): Award Winning ICU Designs: How to build a better facility for patients and caregivers. Society of Critical Care Medicine, 2010
17. Guidelines for intensive care unit design. Guidelines/Practice Parameters Committee of the American College of Critical Care Medicine, Society of Critical Care Medicine. Crit Care Med 1995; 23:582-588

18. Ferri M, Zygun DA, Harrison A, Stelfox HT. Evidence-based design in an intensive care unit: End-user perceptions. BMC Anesthesiology 2015;15:57

19. Trochelman K, Albert N, Spence J, Murray T. Patients and Their Families Weigh in on Evidence-Based Hospital Design. Crit Care Nurse. 2012;32:e1-10.

20. Sadler B, Joseph A, Keller A, Rostenberg B. Using Evidence-Based Environmental Design to Enhance Safety and Quality. Cambridge, Massachusetts: Innovation Series 2009;2009:1-25.

21. Kesecioglu J, Schneider MME, van der Kooi AW, Bion J. Structure and function: planning a new ICU to optimize patient care. CurrOpinCrit Care. 2012;18(6):688-692.

22. Minvielle E, Dervaux B, Retbi A, Aegerter P, Boumendil A, JarsGuincestre MC, et al: Culture, organization, and management in intensive care: construction and validation of a multidimensional questionnaire. J Crit Care 2005; 20:126-138.

23. American Institute of Architects Committee on Architecture for Health and the U.S. Department of Health and Human Services Guidelines for Construction and Equipment/Hospital and Medical Facilities. AIA Press, I 996.

24. The Facility Guidelines Institute: Guidelines for Design and Construction of Health Care Facilities. Chicago, IL, The Facility Guidelines Institute, 2018

25. Thompson DR, Hamilton DK, Cadenhead CD, Swoboda SM, Schwindel $S M$, Anderson DC, et al. Guidelines for intensive care unit design. Crit Care Med. 2012;40:1586-600.

26. The Facility Guidelines Institute: Guidelines for Design and Construction of Health Care Facilities. Chicago, IL, The Facility Guidelines Institute, 2018

27. Chaudhury $H$, Mahmood A, Valente, M: Advantages and disadvantages of single versus multiple occupancy rooms in acute care environments: A review and analysis of the literature. Environment and Behavior 2005;37:760-786

28. Chaudhury H, Mahmood A, Valente M: Nurses' perception of single occupancy versus multi occupancy rooms in acute care environments: An exploratory comparative assessment. ApplNurs Res 2006;19:118-125

29. Bracco D, Dubois M-J, Bouali R, Eggimann P. Single rooms may help to prevent nosocomial bloodstream infection and cross-transmission of methicillin-resistant Staphylococcus aureus in intensive care units. Intensive Care Med. 2007;33:836-40. 
30. Cepeda JA, Whitehouse T, Cooper B, Hails J, Jones K, Kwaku F, et al. Articles Isolation of patients in single rooms or cohorts to reduce spread of MRSA in intensive-care units: prospective two-centre study. Lancet. 2005;365:295-304.

31. Halpern NA. Innovative designs for the smart ICU: part1: from initial thoughts to occupancy. Chest. 2014;145(2):399-403.

32. Williams SV. How many intensive care beds are enough? Crit Care Med. 1983;11(6):412-416.

33. Bertolini G, Rossi C, Brazzi L, Radrizzani D, Rossi G, Arrighi E, et al. The relationship between labour cost per patient and the size of intensive care units: a multicentre prospective study. Intensive Care Medicine 2003;29(12):2307-2311.

34. Simchen E, Sprung CL, Galai N, Zitser-Gurevich Y, Bar-Lavi Y, Gurman $\mathrm{G}$, et al. Survival of critically ill patients hospitalized in and out of intensive care units under paucity of intensive care unit beds. Crit Care Med. 2004;32(8):1654-1661.

35. Robert R, Reignier J, Tournoux-Facon C, Boulain T, Lesieur O, Gissot V, et al. Association des Réanimateurs du Centre Ouest Group. Refusal of intensive care unit admission due to a full unit: impact on mortality. Am J Respir Crit Care Med. 2012;185(10):1081-1087.

36. Ulrich RS, Zimring C, Zhu X, DuBose J, Seo H-B, Choi Y-S, et al. A review of the research literature on evidence-based healthcare design. HERD. 2008;1:61-125.

37. Bartley JM, Olmsted RN, Haas J: Current views of health care design and construction: Practical implications for safer, cleaner environments. Am J Infect Control 2010;38:S1-S12.

38. Harvey MA. Critical-care-unit bed side design and furnishing: Impact on nosocomial infections. Infect Control Hosp Epidemiol 1998;19:597-601.

39. Rashid M. Developing scales to evaluate staff perception of the effects of the physical environment on patient comfort, patient safety, patient privacy, family integration with patient care, and staff working conditions in adult intensive care units: a pilot study. Crit Care Nurs Q. 2007;30:271-283.

40. O'Connell NH, Humphreys $\mathrm{H}$. Intensive care unit design and environmental factors in the acquisition of infection. J Hosp Infect 2000;45:255-262.

41. Graven SN. Clinical research data illuminating the relationship between the physical environment \& patient medical outcomes. J Healthc Des 1997;9:15-19; discussion 21-24.

42. Harvey MA. Evidence-based approach to family care in the intensive care unit: Why can't we just be decent? Crit Care Med 2004;32:19751976.

43. Hamilton D, Thompson D. What's new in ICU design. Critical Connections, Society of Critical Care Medicine, 2005, pp 1-10

44. Wunsch $\mathrm{H}$, Gershengorn $\mathrm{H}$, Mayer $\mathrm{S}$, Claassen J. The effect of window rooms on critically ill patients with subarachnoid hemorrhage admitted to intensive care. Crit Care. 2011;15:R81.

45. Kaufman JE (ed). IES Lighting Handbook. Illuminating Engineering Society of North America; New York, N.Y., 1987, pp. 7-7 through 7-22.

46. Balogh D, Kittinger E, Benzer et. al. Noise in the Intensive Care. Intensive Care Medicine. 1993;19:343-346.

47. Kam PCA, Kam AC, Thompson JF. Noise pollution in the anaesthetic and intensive care environment. Anaesthesia. 1994;49:982-986.

48. Grumet GW. Pandemonium in the modern hospital (editorial). N Engl J Med 1993;328:433-437.

49. Stoddard JC. Design, staffing and equipment requirements for an intensive care unit. Int Anesthesiol Clin 1981;19:77-95.

50. Quinio P, Baczynski S, Dy L, Ferrec G, Catineau J, de Tinténiac A. Evaluation of a medical equipment checklist before intensive care room opening. Ann Fr Anesth Reanim. 2003;22:284-290.

51. Hähnel J, Friesdorf W, Schwilk B, Marx T, Blessing S. Can a clinician predict the technical equipment a patient will need during intensive care unit treatment? An approach to standardize and redesign the intensive care unit workstation. J Clin Monit 1992;8:1-6.

52. Wunsch H, Wagner J, Herlim M, Chong DH, Kramer AA, Halpern SD. ICU occupancy and mechanical ventilator use in the United States. Crit Care Med. 2013;41(12):2712-2719.
53. Bastos PG, Knaus WA, Zimmerman JE, Magalhaes A Jr, Sun X, Wagner DP. The importance of technology for achieving superior outcomes from intensive care. Brazil APACHE III Study Group. Intensive Care Med 1996;22:664-669.

54. Amin P, Fox-Robichaud A, Divatia JV, Pelosi P, Altintas D, Eryüksel E, et al. The intensive care unit specialist: report from the Task Force of World Federation of Societies of Intensive and Critical Care Medicine, J Crit Care. 2016;35:223-228.

55. Guidelines for training in intensive care medicine. European Society of Intensive Care Medicine. Intensive Care Med 1994;20:80-81.

56. Carson SS, Stocking C, Podsadecki T, Christenson J, Pohlman A, MacRae $S$, et al. Effects of organizational change in the medical intensive care unit of a teaching hospital: a comparison of "open" and "closed" formats. JAMA. 1996;276:322-328.

57. Multz AS, Chalfin DB, Samson IM, Dantzker DR, Fein AM, Steinberg $\mathrm{HN}$, et al. A "Closed" Medical Intensive Care Unit (MICU) Improves Resource Utilization When Compared with an "Open" MICU. Am J Respir Crit Care Med 1998;157:1468-1473.

58. Schmalenberg C, Kramer M. Types of intensive care units with the healthiest, most productive work environments. Am J Crit Care 2007;16:458-468 quiz 469.

59. Brown JJ, Sullivan G. Effect on ICU mortality of a full-time critical care specialist. Chest 1989;96:127-129.

60. Mallick R, Strosberg M, Lambrinos J, Groeger JS. The intensive care unit medical director as manager: impact on performance. Med. Care 1995;33:611-624.

61. Wunsch H, Angus DC, Harrison DA, Collange O, Fowler R, Hoste EA, et al. Variation in critical care services across North America and Western Europe. Crit Care Med 2008;36:2787-2793.

62. Dimick JB, Pronovost PJ, Heitmiller RF, Lipsett PA. Intensive care unit physician staffing is associated with decreased length of stay, hospital cost, and complications after esophageal resection. Crit Care Med 2001;29:753-758.

63. Durbin CG Jr. Team model: Advocating for the optimal method of care delivery in the intensive care unit. Crit Care Med 2006;34: S12-S17.

64. Recommendations for Services and Personnel for Delivery of Care in Critical Care Settings. Critical Care Medicine 1988;16(8):809-811.

65. Reynolds HN, Haupt MT, Thill-Baharozian MC, Carlson RW. Impact of critical care physician staffing on patients with septic shock in a university hospital medical intensive care unit. JAMA. 1988;260:34463450.

66 Leapfrog Hospital survey. Factsheet: ICU Physician Staffing 2016. www.leapfroggroup.org/survey

67. Burchardi $\mathrm{H}$, Moerer O. Twenty-four-hour presence of physicians in the ICU. Critical Care 2001;5:131-137.

68. Brilli RJ, Spevetz A, Branson RD, Campbell GM, Cohen H, Dasta JF, et al. Critical care delivery in the intensive care unit: defining clinical roles and the best practice model. Crit Care Med 2001;29:2007-2019.

69. National AHP and HCS Critical Care Advisory Group (UK): Allied Health Professionals (AHP) and Healthcare Scientists (HCS) critical care staffing guidance. A guideline for AHP and HCS Staffing levels (2003).

70. Dang D, Johantgen ME, Pronovost PJ, Jenckes MW, Bass EB. Postoperative complications: does intensive care unit staff nursing make a difference? Heart Lung 2002;31:219-228.

71. Reis Miranda D, Moreno R, lapichino G. Nine equivalents of nursing manpower use score (NEMS). Intensive Care Med 1997;23:760-765.

72. Iapichino G, Radrizzani D, Pezzi A, Assi E, Di Mauro P, Mistraletti G, et al. Evaluating daily nursing use and needs in the intensive care unit: a method to assess the rate and appropriateness of ICU resource use. Health Policy 2005;73:228-234.

73. lapichino G, Radrizzani D, Rossi C, Pezzi A, Anghileri A, Boffelli S, et al. Proposal of a flexible structural-organizing model for the intensive care units. Minerva Anestesiol 2007;73:501-506.

74. Tarnow-Mordi WO, Hau C, Warden A, Shearer AJ. Hospital mortality in relation to staff workload: a 4-year study in an adult intensive-care unit. Lancet 2000;356:185-189. 
75. van Beek AP, Wagner C, Spreeuwenberg PP, Frijters DH, Ribbe MW, Groenewegen PP. Communication, advice exchange and job satisfaction of nursing staff: a social network analyses of 35 long-term care units. BMC Health Serv Res. 2011;11:140.

76. Moreno R, Reis Miranda D. Nursing staff in intensive care in Europe: the mismatch between planning and practice. Chest 1998;113:752-758.
77. Standards for Healthcare Facilities. National Fire Prevention Association, Quincy, MA, 1990, sections 3-4.1.2.1 and 3-3.2.1.1.

78. National Fire Protection Association: NFPA 101: Life Safety Code. Quincy, MA, National Fire Protection Association, 2006.

79. Stelfox HT, Bates DW, Redelmeier D. Safety of patients isolated for infection control. JAMA. 2003;290:1899-905. 
'Department of Critical Care Foundation, Critical Care, MJ Rajasthan Hospital, Jaipur, Rajasthan, India, e-mail: drnrungta@yahoo.com 2Department of Neuro Trauma Unit, Grant Medical Foundation, Pune, Maharashtra, India, Phone: 9822844212, e-mail: kapilzirpe@gmail.com ${ }^{3}$ Department of Critical Care, Sanjeevan \& MJM Hospital, Pune, Maharashtra, India, Phone: +91-9822050240, 020-25531539 / 25539538, e-mail: subhaldixit@gmail.com

${ }^{4}$ Department of Critical Care and Anesthesiology, Medanta The Medicity, Sector-38, Gurgaon, Haryana, India, Phone: + 911244141414 Extn. 3335, e-mail ID: yatinmehta@hotmail.com

${ }^{5}$ Department of Pulmonary and Critical Care Medicine, University of Health Sciences, Rohtak, Haryana, India, Phone: 9991101616 , e-mail: drchaudhrydhruva@gmail.com

${ }^{6}$ Department of Critical Care , Medanta Hospital, The Medicity, Gurugram, Haryana, India, Phone: 91-11-26692531, e-mail: drdeepak_govil@ yahoo.co.in

${ }^{7}$ Department of Critical Care, Saneejivini Hospital, Vastrapur, Ahmedabad, Gujarat, India, Phone: +91-9924231500, e-mail: mishr.c@gmail.com ${ }^{8}$ Department of Critical Care, Artemis Health Institute, Gurgaon, Haryana, India, Phone: 7042118485, e-mail: drjeetendrasharma@gmail.com

${ }^{9}$ JLN Medical College, Jaipur, Rajasthan, India, e-mail: pamin@vsml.com

${ }^{10}$ Department of Critical care \& Emergency Medicine, Sir Ganga Ram Hospital, Delhi, India, e-mail: chairman@nabh.co

${ }^{11}$ Department of Pulmonary, Critical Care and Sleep Medicine, PSRI Hospital, New Delhi, India, Phone: +91-9810 353 696, e-mail: gckhil@gmail. com

${ }^{12}$ Department of Pediatrics, Post Graduate Institute of Medical Sciences, Rohtak, Haryana, India, e-mail: kundanmittal@yahoo.co.in

${ }^{13}$ Rajendra Institute of Medical Sciences, Ranchi, Jharkhand, India, Phone: 91-0755-6679101, e-mail: drpradipkb@gmail.com

${ }^{14}$ Department of Critical Care, SGPGl, Lucknow, Uttar Pradesh, India, e-mail: arvindbaronia@hotmail.com

${ }^{15}$ Department of Critical Care, Anesthesia and Emergency Medicine, Regency Health, Lucknow, Uttar Pradesh, India, Phone: 91-9818716943, e-mail: dryashjaveri@yahoo.com

${ }^{16}$ Department of Anesthesia, Critical Care and Pain, Tata Memorial Hospital, Mumbai, Maharashtra, India, e-mail: sheila150@gmail.com

${ }^{17}$ Department of Anesthesia, JLN Medical College, Jaipur, Rajasthan, India, e-mail: neenarungta@gmail.com

${ }^{18}$ Department of Anaesthesia and Critical Care Medicine, Synergy Plus hospital, NH 2 Sikandra, Agra, Uttar Pradesh, India, e-mail: drranvirstyagi@ gmail.com

${ }^{19}$ Eminent Hospital, 6/1 Old Palasia, Opposite Barwani Plaza, Indore, Madhya Pradesh, India, e-mail: dhanuka67@rediffmail.com

${ }^{20}$ Department of Surgery, Mahatma Gandhi University of Medical Sciences \& Technology, Riico Institutional Area, Tonk Road, Sitapura, Jaipur, Rajasthan, India, e-mail: mcmisra@gmail.com

${ }^{21}$ Department of Critical Care, Virinchi Hospital, Hyderabad, Telangana, India, Phone: 9866343632, e-mail: srinivas3271@gmail.com 